\title{
Analisis Kesalahan Mahasiswa dalam Menyelesaikan Masalah Program Linier dengan Metode Simpleks
}

\author{
Erna Puji Astutik \\ Program Studi Pendidikan Matematika, Fakultas Sains dan Teknologi, Universitas PGRI Adi Buana Surabaya, \\ Jl. Dukuh Menanggal XII-4, Surabaya, Indonesia \\ erna_pa@unipasby.ac.id
}

\begin{abstract}
This study aims to describe the error analysis which includes the form and causes of errors in solving linear programming problems based on the Newman stages which include reading, comprehension, transformation, process skill, and encoding. The research was conducted with a qualitative approach where in the first stage a linear programming problem solving test was carried out on students of class 2017 mathematics education department. After that, 3 students with the lowest problem solving skills were selected to conduct interviews. Interviews aim to confirm student answers and explore information about the form and causes of student errors. To describe the form of student error in solving linear programming problems, researcher used data obtained from the test and interviews which were then triangulated to ensure the validity of the data. Meanwhile, the causes of errors were obtained only from interviews. Based on the results of data analysis, it was found that students made mistakes in solving linear programming problems with the simplex method, which is located at the stage of transformation, process skills, and encoding where students still experience errors in calculation process in the simplex table. As for the factors that cause student errors in solving linear programming problems with the simplex method are counting errors, inaccuracy, and time management.
\end{abstract}

Keywords: error analysis, problem solving, linear programming, simplex

\begin{abstract}
Abstrak
Penelitian ini bertujuan untuk mendeskripsikan analisis kesalahan yang meliputi bentuk dan penyebab kesalahan dalam menyelesaikan masalah program linier berdasarkan tahapan newman yang meliputi: 1) membaca soal (reading), 2) memahami masalah (comprehension), 3) transformasi (transformation), 4) keterampilan proses (process skill), dan 5) penulisan jawaban akhir (encoding). Penelitian dilakukan dengan pendekatan kualitatif dimana pada tahap pertama dilakukan tes penyelesaian masalah program linier pada mahasiswa angkatan 2017 semester gasal Tahun Ajaran 2019-2020. Setelah itu dipilih 3 mahasiswa dengan kemampuan menyelesaikan masalah terendah untuk dilakukan wawancara. Wawancara bertujuan untuk mengkonfirmasi jawaban mahasiswa serta menggali informasi tentang letak dan penyebab kesalahan mahasiswa dalam menyelesaikan masalah program linier. Untuk mendeskripsikan bentuk kesalahan mahasiswa dalam menyelesaikan masalah program linier, peneliti menggunakan data yang diperoleh dari hadil tes dan dan wawancara yang kemudian ditriangulasikan untuk memastikan keabsahan data. Sedangkan penyebab kesalahan diperoleh hanya dari hasil wawancara. Berdasarkan hasil analisis data, diperoleh hasil bahwa mahasiswa melakukan kesalahan dalam menyelesaikan masalah program linier dengan metode simpleks yaitu terletak pada tahap transformasi, keterampilan proses, dan penulisan jawaban dimana mahasiswa masih mengalami kesalahan dalam proses perhitungan pada tabel simpleks. adapun faktor penyebab kesalahan mahasiswa dalam menyelesaikan masalah program linier dengan metode simpleks adalah kesalahan menghitung, kurang teliti, dan pengaturan waktu ketika mengerjakan.
\end{abstract}

Kata kunci: analisis kesalahan, pemecahan masalah, program linier, simpleks

Copyright (c) 2021 Erna Puji Astutik

$\triangle$ Corresponding author: Erna Puji Astutik

Email Address: erna_pa@unipasby.ac.id (J1. Dukuh Menanggal XII-4, Surabaya, Indonesia)

Received 30 Januari 2021, Accepted 26 Februari 2021, Published 27 Maret 2021

\section{PENDAHULUAN}

Dalam mata kuliah Operasional Riset khususnya pada materi Program Linier mahasiswa diharapkan dapat memahami konsep sistem persamaan dan pertidaksamaan linier $\mathrm{n}$ variabel dan menerapkannya dalam pemecahan masalah program linear, serta menerapkan prosedur yang sesuai untuk menyelesaikan masalah program linear terkait masalah nyata dan menganalisis kebenaran 
langkah-langkahnya. Program linier (linear programming) merupakan model optimasi persamaan linear yang berkenaan dengan masalah-masalah pertidaksamaan linier (Khairuddin, 2013). Program linier berkaitan dengan masalah nilai optimum yang meliputi nilai maksimum atau minimum sebuah fungsi linear pada suatu sistem pertidaksamaan linear yang harus memenuhi optimasi fungsi objektif. Untuk menyelesaikan masalah program linier tersebut dapat dilakukan dengan metode grafik, metode simpleks atau dengan bantuan software. Metode grafik penggunaannya hanya dibatasi pada dua variabel karena pada grafik hanya terdapat dua sumbu yaitu sumbu vertikal dan horisontal (Zulfikarijah, 2004). Sedangkan metode simpleks dapat digunakan untuk permasalahan program linier dengan jumlah variabel tiga atau lebih. Selain itu, penggunaan software MATLAB juga dapat digunakan untuk menyelesaikan masalah program linier (Astutik \& Fitriatien, 2018, 2019).

Berdasarkan observasi di kelas Operasional Riset dan hasil Ujian Tengah Semester Genap 20172018 di Program Studi Pendidikan Matematika Universitas PGRI Adi Buana Surabaya, mahasiswa banyak mengalami kesalahan dalam menyelesaikan permasalahan Program Linier dalam memodelkan soal cerita ke dalam bentuk matematika serta menyelesaikan dengan metode simpleks untuk permasalahan yang melibatkan tiga variabel atau lebih.

Menurut Manibuy, Mardiyana, \& Saputro (2014) kesalahan merupakan penyimpangan dalam menyelesaikan soal. Dalam matematika, kesalahan umumnya dialami oleh mahasiswa meliputi kesalahan dalam memahami konsep, memahami simbol dan tanda, memilih dan menggunakan prosedur penyelesaian, menggunakan rumus, dan menghitung. Bentuk-bentuk kesalahan tersebut sesuai dengan tahapan analisis kesalahan menurut Newman yang biasa disebut Newman's Error Analisis (NEA). NEA umumnya digunakan dalam menganalisis kesalahan soal cerita matematis dengan tahapan-tahapan: 1) membaca soal (reading), 2) memahami masalah (comprehension), 3) transformasi (transformation), 4) keterampilan proses (process skill), dan 5) penulisan jawaban akhir (encoding) (Clements, 1980; Sughesti, Muhsetyo, \& Susanto, 2016)

Dalam pemecahan masalah program linier, berdasarkan penelitian yang dilakukan oleh Octaria (2016), mahasiswa banyak melakukan kesalahan pada tahap pemodelan matematika dan perhitungan. Sedangkan menurut Sumargiyani, Yusnia, \& Abidah (2019), mahasiswa melakukan kesalahan paling banyak pada tahap membaca dan memahami masalah. Setelah mengetahui letak kesalahan maka perlu diidentifikasi juga penyebab kesalahan tersebut dimana faktor penyebab kesalahan dapat berasal dari dalam (intern) yang bersifat kognitif, afektif, dan psikomotor maupun dari luar (ekstern) yang berasal dari lingkungan baik keluarga, masyarakat, maupun sekolah atau kampus (Syah, 2005). Sebagaian besar faktor penyebab kesalahan dalam pemecahan masalah berasal dari dalam diri siswa seperti penguasaan konsep, tergesa-gesa, kurang teliti, tidak mampu memahami masalah, dan tidak mampu menyelesaikan masalah sesuai dengan prosedur yang sesuai (Dewi \& Kartini, 2021; Hanipa \& Sari, 2017).

Kesalahan mahasiswa dalam menyelesaikan masalah program linier perlu dianalisis lebih lanjut untuk mengetahui letak kesalahan dan penyebab adanya kesalahan tersebut sehingga mendapatkan 
gambaran yang jelas dan rinci atas kelemahan siswa dalam menyelesaikan masalah program linier (Nurussafa'at, Sujadi, \& Riyadi, 2016).

Berdasarkan latar belakang, tujuan penelitian ini adalah untuk mendeskripsikan letak kesalahan dan faktor penyebab kesalahan mahasiswa dalam menyelesaikan masalah Program Linier. Dengan adanya gambaran kesalahan yang jelas diharapkan dapat memperbaiki kemampuan penyelesaian masalah program linier mahasiswa kedepannya.

\section{METODE}

Penelitian ini menggunakan pendekatan kualitatif yang bertujuan untuk mendeskripsikan letak dan penyebab kesalahan mahasiswa dalam menyelesaikan masalah program linier. Pada tahap pertama dilakukan tes penyelesaian masalah program linier pada mahasiswa kelas 2017A Program Studi Pendidikan Matematika Universitas PGRI Adi Buana Surabaya semester gasal Tahun Ajaran 20192020. Setelah itu dipilih 3 mahasiswa dengan kemampuan menyelesaikan masalah terendah untuk dilakukan wawancara. Wawancara bertujuan untuk mengkonfirmasi jawaban mahasiswa serta menggali informasi tentang letak dan penyebab kesalahan mahasiswa dalam menyelesaikan masalah program linier.

Analisis data dalam penelitian ini dilakukan untuk menjawab rumusan masalah yaitu mendeskripsikan bentuk dan penyebab kesalahan mahasiswa dalam menyelesaikan masalah program linier. Peneliti menggunakan model analisis Miles and Huberman, yang meliputi reduksi data, penyajian data dan kesimpulan (Sugiyono, 2017). Pada tahap reduksi data, data yang diperoleh dari log book atau diary peneliti, akan ditranskripsi kemudian direduksi dengan memfokuskan pada hal-hal yang pokok dengan cara mencari tema dan polanya serta membuang data yang tidak perlu. Langkah selanjutnya, peneliti menyajikan data dalam bentuk uraian singkat maupun teks yang bersifat naratif berdasarkan tema yang telah ditentukan. Langkah terakhir dalam tahap analisis data adalah penarikan kesimpulan dan verifikasi berdasarkan data yang telah diperoleh dari berbagai sumber.

Untuk mendeskripsikan bentuk kesalahan mahasiswa dalam menyelesaikan masalah program linier, peneliti menggunakan data yang diperoleh dari hasil tes dan wawancara yang kemudian ditriangulasikan untuk memastikan keabsahan data. Sedangkan penyebab kesalahan diperoleh hanya dari hasil wawancara.

\section{HASIL DAN DISKUSI}

Data kesalahan mahasiswa dalam menyelesaikan masalah program linier diperoleh dari data hasil tes dan wawancara. Tes berupa pemecahan masalah program linier yang hasil jawabannya dikonfirmasi dengan wawancara kemudian dianalisis dengan tahapan analisis kesalahan Newman yang meliputi tahap membaca, memahami, transformasi, keterampilan proses, dan penulisan jawaban. Berikut disajikan hasil analisis letak kesalahan dan penyebab kesalahan Subyek pertama, Subyek kedua, dan Subyek ketiga dalam menyelesaikan permasalahan program linier. 


\section{Tahap Membaca}

Tahap pertama yaitu membaca. Subyek pertama, kedua, dan ketiga mampu membaca dan mengenali variabel dalam soal. Hal tersebut didukung dengan hasil wawancara dimana mereka mampu menjelaskan apa saja yang diketahui dan ditanyakan dalam soal. Sehingga dapat disimpulkan bahwa ketiga subyek tidak melakukan kesalahan pada tahap membaca.

\section{Tahap Memahami}

Tahap kedua yaitu tahap memahami sebagaimana pada tahap membaca, berdasarkan hasil tes, subyek pertama, kedua, dan ketiga mampu memahami informasi yang diketahui dalam soal dengan menuliskan hal-hal yang diketahui dan ditanyakan sebagaimana gambar 1 berikut.
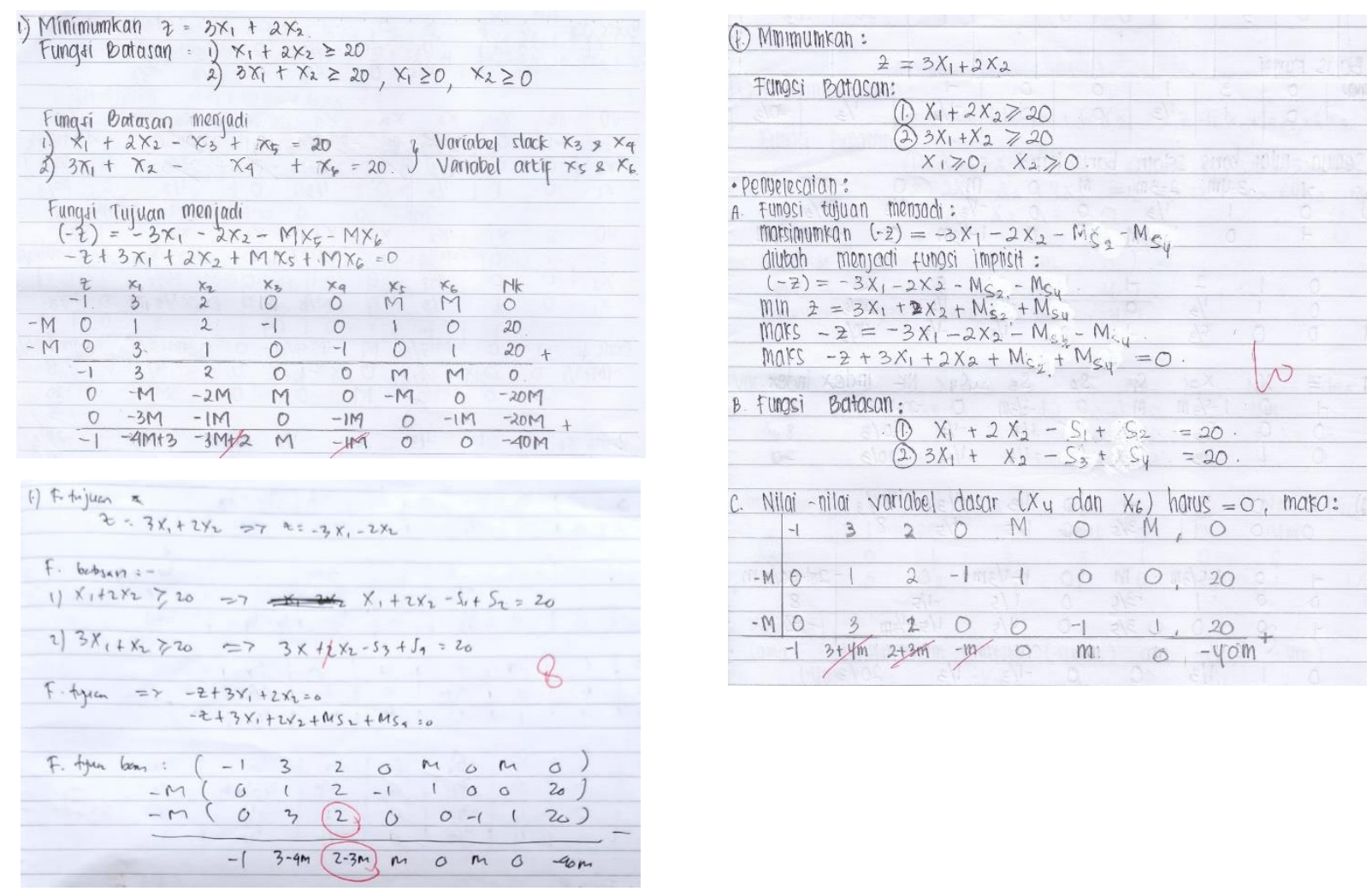

Gambar 1. Jawaban Subyek 1, 2, dan 3 pada Tahap Memahami dan Tahap Transformasi

Hal tersebut sesuai dengan penelitian Astutik (2019) dan Nugroho \& Dwijayanti (2019) bahwa untuk memahami masalah, subyek mengidentifikasi dan menuliskan informasi penting yang ada dalam soal. Selain itu, berdasarkan hasil wawancara, subyek mampu memahami soal dengan menyebutkan halhal yang diketahui dan ditanyakan. Berdasarkan hasil tes dan wawancara, dapat disimpulkan bahwa ketiga subyek tidak melakukan kesalahan pada tahap memahami.

\section{Tahap Transformasi}

Tahap ketiga yaitu tahap transformasi. Berdasarkan hasil tes, diperoleh data kesalahan subyek pertama, kedua, dan ketiga ketika melakukan transformasi fungsi kendala dan fungsi tujuan. Fungsi kendala dan fungsi tujuan merupakan hal terpenting yang perlu dilakukan dalam penyelesaian program linier (Yuwono \& Istiani, 2007).

Subyek pertama melakukan kesalahan ketika mentransformasi fungsi tujuan. Hal tersebut 
didukung dengan hasil wawancara dimana subyek pertama melakukan kesalahan ketika mentransformasi fungsi tujuan yang harusnya bernilai $-3 \mathrm{M}+2$ tetapi ditulis $-\mathrm{M}+2$. Adapun penyebab kesalahan tersebut dikarenakan kesalahan dalam menghitung sebagaimana kutipan wawancara berikut.

"Satu kali negatif M. Oh harusnya negatif M, berarti ini -3M+2. Saya salah menghitung".

Begitu juga subyek kedua melakukan kesalahan ketika melakukan transformasi fungsi tujuan dimana koefisien-koefisien variabel dari fungsi tujuan yang harusnya bernilai $-4 M+3,-3 M+2$, dan $M$ tetapi dijawab dengan $3+4 \mathrm{M}, 2+3 \mathrm{M}$, dan $-\mathrm{M}$ yang disebabkan karena kesulitan dalam menghitung sebagaimana kutipan wawancara berikut.

“... yang di sini kemarin saya coret satu satu bu tapi hasilnya ternyata masih salah...

karena saya kesulitan menghitung bu".

Sedangkan subyek ketiga melakukan kesalahan ketika melakukan transformasi pada fungsi kendala dan fungsi tujuan. Subyek ketiga mengalami kesalahan ketika melakukan transformasi fungsi batasan yang kedua yang seharusnya X2 dijawab 2 X2 sebagaimana hasil wawancara yang menyebutkan bahwa S3 salah menulis hasil transformasi yang seharusnya X2 ditulis 2X2. Selain itu, subyek ketiga juga melakukan kesalahan ketika melakukan transformasi pada fungsi tujuan dimana nilai koefisien X2 pada fungsi tujuan bernilai benar meskipun koefisien X2 pada fungsi tujuan kedua bernilai salah. Hal tersebut dijawab oleh subyek ketiga pada saat wawancara dimana subyek ketiga menyebutkan bahwa kesalahan itu terjadi dikarenakan salah dalam menulis.

Berdasarkan hasil tes dan wawancara, dapat disimpulkan bahwa ketiga subyek melakukan kesalahan pada tahap transformasi dikarenakan kesalahan dalam menulis dan menghitung.

\section{Tahap Keterampilan Proses}

Pada tahap ini, subyek pertama, kedua, dan ketiga menjawab soal dengan langkah-langkah yang sesuai prosedur akan tetapi mereka mengalami kesalahan dikarenakan kesalahan dalam perhitungan ketika menyelesaikan dengan metode simpleks. Hal tersebut didukung dengan hasil wawancara dimana mereka mampu menjelaskan prosedur dalam penyelesaian soal walaupun tidak mampu menyelesaikan dikarenakan salah perhitungan. Berdasarkan hasil tes dan wawancara tersebut, dapat disimpulkan bahwa ketiga subyek melakukan kesalahan pada tahap keterampilan proses dikarenakan salah melakukan perhitungan. Hasil tersebut sesuai dengan penelitian yang dilakukan oleh Hariyani \& Aldita (2020) bahwa kesalahan yang terjadi pada tahap keterampilan proses disebabkan karena subyek tidak melakukan perhitungan dengan benar.

\section{Tahap Penulisan Jawaban}

Tahap kelima yaitu tahap penulisan jawaban. Subyek pertama, kedua, dan ketiga tidak mampu menemukan hasil akhir dari soal berdasarkan prosedur atau langkah-langkah yang telah digunakan. Hal tersebut didukung dengan hasil wawancara dimana subyek pertama menyebutkan bahwa tidak dapat menemukan hasil akhir dikarenakan kesalahan perhitungan dari awal sebagaimana kutipan wawancara berikut.

“... Bingung semua bu karena sudah salah dari awal. Saya kemarin itu sebelum ini saya 
nemu hasilnya negatif di X1 dan X4. X4 itu yang paling rendah nilai negatifnya, saya

ketemunya negatif terkecil di X4 bukan X2 sehingga mempengaruhi kesalahan seterusnya..."

Begitu juga subyek kedua yang menyebutkan bahwa tidak dapat menemukan hasil akhir dikarenakan kesalahan perhitungan dari awal sebagaimana kutipan wawancara berikut.

“... sudah salah dari awal jadi hasilnya salah. mempengaruhi pemilihan variabel dasar dan kolom kunci".

Subyek ketiga juga menyebutkan hal yang sama bahwa tidak dapat menemukan hasil akhir dikarenakan kesalahan perhitungan dari awal.

Berdasarkan hasil tes dan wawancara, dapat disimpulkan bahwa subyek pertama, kedua, dan ketiga melakukan kesalahan pada tahap penulisan jawaban dikarenakan kesalahan perhitungan sehingga tidak menemukan jawaban akhir.

Berdasarkan paparan hasil tes dan wawancara dapat dirangkum hasil analisis kesalahan mahasiswa dalam menyelesaikan masalah program linier sebagaimana tabel 1 berikut.

Tabel 1. Hasil Analisis Kesalahan Mahasiswa dalam Menyelesaikan Masalah Program Linier

\begin{tabular}{|c|l|l|}
\hline Subyek & \multicolumn{1}{|c|}{ Jenis kesalahan } & \multicolumn{1}{c|}{ Faktor penyebab kesalahan } \\
\hline \multirow{2}{*}{1} & Transformasi & kesalahan perhitungan \\
\cline { 2 - 3 } & Keterampilan proses & kesalahan perhitungan \\
\cline { 2 - 3 } & Penulisan jawaban & kesalahan perhitungan \\
\hline \multirow{2}{*}{$\mathbf{2}$} & Transformasi & kesulitan dalam menghitung \\
\cline { 2 - 3 } & Keterampilan proses & kesalahan perhitungan \\
\cline { 2 - 3 } & Penulisan jawaban & kesalahan perhitungan \\
\hline \multirow{3}{*}{} & Transformasi & kesalahan menulis atau menghitung \\
\cline { 2 - 3 } & Keterampilan proses & kesalahan menghitung \\
\cline { 2 - 3 } & Penulisan jawaban & kesalahan menghitung \\
\hline
\end{tabular}

Berdasarkan tabel 1, dapat disimpulkan bahwa dalam menyelesaikan masalah program linier dengan metode simpleks, mahasiswa banyak melakukan kesalahan pada tahap transformasi, keterampilan proses, dan penulisan jawaban. Adapun sebagian besar kesalahan tersebut terjadi dikarenakan kesalahan dalam penulisan maupun perhitungan. Hasil ini sesuai dengan penelitian yang dilakukan oleh Octaria (2016) dimana kesalahan yang banyak dilakukan oleh mahasiswa ketika menyelesaikan masalah program linier dengan metode simpleks terletak pada kesalahan dalam melakukan perhitungan. Akan tetapi berbeda dengan hasil penelitian yang dilakukan oleh Sumargiyani dkk. (2019) bahwa mahasiswa banyak melakukan kesalahan pada tahap membaca dan memahami. Dengan adanya perbedaan hasil penelitian ini akan semakin menambah informasi tentang jenis dan penyebab kesalahan mahasiswa dalam menyelesaikan masalah program linier, sehingga kedepannya 
dapat dilakukan penelitian untuk mencari solusi dari jenis dan penyebab kesalahan tersebut.

\section{KESIMPULAN}

Berdasarkan hasil penelitian dapat disimpulkan bahwa kesalahan mahasiswa dalam menyelesaikan masalah program linier dengan metode simpleks yaitu terletak pada tahap transformasi, keterampilan proses, dan penulisan jawaban dimana mahasiswa masih mengalami kesalahan dalam proses perhitungan pada tabel simpleks. Sedangkan faktor penyebab kesalahan mahasiswa dalam menyelesaikan masalah program linier dengan metode simpleks adalah adanya kesalahan dalam menghitung, kurang teliti dalam mengerjakan, dan pengaturan waktu ketika mengerjakan.

\section{UCAPAN TERIMA KASIH}

Ucapan terimakasih peneliti ucapkan kepada Universitas PGRI Adi Buana Surabaya yang telah memberikan bantuan dana berupa Hibah Adi Buana sehingga penelitian ini dapat terlaksana. Terimakasih juga peneliti ucapkan kepada para dosen dan mahasiswa program studi pendidikan matematika Universitas PGRI Adi Buana Surabaya yang telah membantu dalam proses penelitian.

\section{REFERENSI}

(Ken) Clements, M. A. (1980). Analyzing Children's Errors on Written Mathematical Tasks. Educational Studies in Mathematics. https://doi.org/10.1007/BF00369157

Astutik, E. P. (2019). Profil Pemecahan Masalah Program Linier dengan Metode Simpleks. Seminar Nasional Hasil Riset Dan Pengabdian (SNHRP) II, 450-458.

Astutik, E. P., \& Fitriatien, S. R. (2018). Integrating MATLAB in Teaching Linear Programming at The University Level. International Journal on Teaching and Learning Mathematics. https://doi.org/10.18860/ijtlm.v1i2.5882

Astutik, E. P., \& Fitriatien, S. R. (2019). Pengaruh Software MATLAB terhadap Kemampuan Menyelesaikan Masalah Program Linier. Fibonacci, 5(2), 175-182.

Dewi, S. P., \& Kartini, K. (2021). Analisis Kesalahan Siswa dalam Menyelesaikan Soal Sistem Persamaan Linear Tiga Variabel Berdasarkan Prosedur Kesalahan Newman. Jurnal Cendekia: Jurnal Pendidikan Matematika, 532-642. https://doi.org/https://doi.org/10.31004/cendekia.v5i1.508

Hanipa, A., \& Sari, V. T. A. (2017). Analisis Kesalahan Siswa Dalam Menyelesaikan Soal Sistem Persamaan Linear Dua Variabel Pada Siswa Kelas VIII MTs di Kabupaten Bandung Barat. Jurnal On Education.

Hariyani, S., \& Aldita, V. C. (2020). Analisis Kesalahan Siswa dalam Menyelesaikan Soal Cerita Sistem 
Persamaan Linear Dua Variabel Berdasarkan Prosedur Newman. Al-Khwarizmi: Jurnal Pendidikan Matematika Dan Ilmu Pengetahuan Alam, 8(1), 39-50. https://doi.org/10.24256/jpmipa.v8i1.805

Khairuddin. (2013). Menyelesaikan Kasus Program Linier Melalui GeoGebra. Retrieved from http://media.p4tkmatematika.org/wp-content/uploads/2013/01/Prolin_Geogebra2.pdf

Manibuy, R., Mardiyana, \& Saputro, D. R. S. (2014). Analisis Kesalahan Siswa Dalam Menyelesaikan Soal Persamaan Kuadrat Berdasarkan Taksonomi Solopada Kelas X SMA Negeri 1 Plus di Kabupaten Nabire - Papua. Jurnal Elektronik Pembelajaran Matematika.

Nugroho, A. A., \& Dwijayanti, I. (2019). Analisis Kemampuan Pemecahan Masalah Mahasiswa Calon Guru Matematika Pada Mata Kuliah Program Linier. AKSIOMA: Jurnal Matematika Dan Pendidikan Matematika. https://doi.org/10.26877/aks.v10i2.4720

Nurussafa'at, F. A., Sujadi, I., \& Riyadi, R. (2016). Analisis Kesalahan Siswa Dalam Menyelesaikan Soal Cerita Pada Materi Volume Prisma Dengan Fong's Shcematic Model for Error Analysis Ditinjau Dari Gaya Kognitif Siswa. Jurnal Pembelajaran Matematika, 4(2).

Octaria, D. (2016). Analisis Kesalahan Mahasiswa Serta Upaya Remediasi dalam Menyelesaikan Soal Simpleks Program Linier. Jurnal Pendidikan Matematika JPM RAFA, 2(2), 269-279.

Sughesti, M. M., Muhsetyo, G., \& Susanto, H. (2016). Jenis Kesalahan Siswa Dalam Menyelesaikan Soal Cerita Berdasarkan Prosedur Newman. ResearchGate.

Sugiyono. (2017). Metode Penelitian Pendidikan (Pendekatan Kuantitatif, Kualitatif dan R\&D). Bandung: Alfabeta.

Sumargiyani, Yusnia, I., \& Abidah, Y. (2019). Analisis Kesalahan dalam Menyelesaikan Soal Program Linear Berdasarkan Teori NEWMAN. AdMathEdu : Jurnal Ilmiah Pendidikan Matematika, Ilmu Matematika Dan Matematika Terapan, 9(2).

Syah, A. (2005). Strategi Belajar Mengajar. Jakarta: Ciputat Press.

Yuwono, B., \& Istiani, P. N. (2007). Bahan Kuliah Riset Operasional. Yogyakarta: Jurusan Teknik Informatika Fakultas Teknologi Industri UPN Veteran Yogyakarta.

Zulfikarijah, F. (2004). Operation Research. Malang: Bayumedia Publishing. 